\title{
SIFAT TOLERANSI ANAKAN RAMIN (Gonystylus bancanus (Miq.) Kurz) TERHADAP NAUNGAN MELALUI PENDEKATAN KARAKTER MORFOLOGI DAN ANATOMI DAUN
}

(The Study of The Character of Tolerancy of Ramin (Gonystylus bancanus (Miq.) Kurz) Seedling to Shading Through Leaf Morphological and Anatomical Characteristic Approach)

\author{
Oleh/By :
}

Tati Rostiwati dan / and Abdurani Muin

\begin{abstract}
The objective of this research was to study shade tolerance of Gonystylus bancanus (Miq.) Kurz seedling at three different light levels. The carried out observation research method was by using two main variables i.e. morphological caharacters (Leaf Area-LA; Specific Leaf Area-SLA; Specific Leaf Weight-SLW) and anatomical characters (leaf tissues and palisade layer thickness, the numbers of stomata per leaf area) of leaf, while supporting variables used in the research was response of twoyear ramin seedling growth (height and diameter) under three light levels at ramin germplasm research plot in Tanjungpura University, West Kalimantan Province. The results showed that G. bancanus seedlings (semitolerant species) had similar morphological characteristic with other tolerant and intolerant group plant species, i.e. SLA of heavy shaded plant was larger than that of moderate shaded and full sunlight seedlings, whereas SLW variables performed contradictory result. Showed significant difference by anatomical characteristic was only number of stomata per leaf area. Highest number of stomata was showed by full sunlight seedlings (282.36) followed by moderate shaded (220.26) and heavy shaded seedlings (205.31) respectively. This agreed with different response shown on the height and diameter growth of full sunlight, moderate shaded and heavy shaded seedlings respectively $(145.12$ $\mathrm{cm}$ and $1.831 \mathrm{~cm} ; 141.13 \mathrm{~cm}$ and $1.536 \mathrm{~cm} ; 98.65 \mathrm{~cm}$ and $1.298 \mathrm{~cm}$ ).
\end{abstract}

Key words: Light environment, morphological character, anatomical character, ramin, tolerancy

\begin{abstract}
ABSTRAK
Tujuan penelitian adalah untuk mengidentifikasi sifat toleransi anakan ramin (Gonystylus bancanus (Miq.) Kurz) yang tumbuh pada tiga kondisi cahaya. Penelitian ini menggunakan metode observasi dengan variabel utama adalah karakter morfologi daun (Luas Daun-Leaf Area/LA; Luas Daun SpesifikSpecific Leaf Area/SLA; Bobot Daun Spesifik-Specific Leaf Weight/SLW) dan karakter anatomi daun (tebal jaringan daun, tebal lapisan palisade, dan jumlah stomata per luasan daun). Sebagai variabel pendukung adalah respon pertumbuhan tinggi anakan ramin umur dua tahun pada tiga kondisi cahaya di plot penelitian plasma nutfah ramin, Universitas Tanjungpura, Provinsi Kalimantan Barat. Hasil penelitian ini adalah anakan $G$. bancanus (jenis semitoleran) mempunyai karakter morfologi yang sama dengan kelompok tumbuhan jenis toleran dan intoleran, yaitu SLA daun tumbuhan yang ternaungi lebih besar dibandingkan dengan SLA daun tumbuhan pada kondisi agak terbuka dan terbuka, sementara SLW menunjukkan keadaan sebaliknya. Pcrbedaan yang nyata yang ditunjukkan oleh karakter anatomi hanya variabel jumlah stomata per luasan daun. Jumlah stomata tertinggi terlihat pada anakan yang tumbuh pada kondisi terbuka $(282,36)$, kemudian diikuti oleh anakan pada kondisi agak terbuka $(220,26)$ dan ternaungi $(205,31)$. Perbedaan tersebut sejalan dengan perbedaan respon pertumbuhan tinggi dan diameternya. Tinggi dan diameter anakan pada kondisi terbuka, agak terbuka, dan ternaungi berturutturut $145,12 \mathrm{~cm}$ dan $1,831 \mathrm{~cm} ; 141,13 \mathrm{~cm}$ dan $1,536 \mathrm{~cm} ; 98,65 \mathrm{~cm}$ dan $1,298 \mathrm{~cm}$.
\end{abstract}

Kata kunci: Kondisi cahaya, karakter morfologi, karakter anatomi, ramin, toleransi

\section{PENDAHULUAN}

Indonesia merupakan negara pengekspor utama kayu ramin (Gonystylus bancanus (Miq.) Kurz) di Asia Tenggara. Oleh karena tingginya permintaan akan bahan baku kayu yang berkualitas di antaranya ramin, maka terjadi penebangan besar-besaran terhadap tegakan ramin di alam, sehingga saat ini ramin sudah masuk ke dalam Convention 
on International Trade of Endangered Species of Wild Fauna and Flora (CITES) Appendix II (Anonymous, 1994). Oleh karena itu untuk tujuan konservasi jenis, maka tegakan ramin dan permudaan alam yang masih ada perlu dipelihara.

Pembinaan tegakan tinggal (Logged Over Area - LOA) secara umum berupa kegiatan pemeliharaan permudaan alam. Pada dasarnya kegiatan tersebut sangat berkaitan erat dengan pengaturan intensitas cahaya yang masuk pada celah-celah tegakan hutan untuk menstimulasi pertumbuhan permudaan alam tersebut. Seperti yang dikemukakan oleh Muin dan Purwita (2002) bahwa untuk membina kawasan bekas penebangan hutan ramin, baik pembebasan permudaan alam maupun penanaman pengayaan perlu memperhatikan intensitas cahaya yang dibutuhkan olch ramin, agar pertumbuhan permudaan alam dan tanaman pengayaan menjadi lebih cepat.

Cahaya berperan sangat penting dalam pengelolaan ekosistem hutan. Kimmins (1987) mengemukakan bahwa pohon-pohon muda yang ada pada kondisi intensitas cahaya rendah (di bawah tegakan pohon), seringkali mempunyai kemampuan untuk bertahan hidup dalam jangka waktu yang lama sampai celah terbentuk. Karakter jenis toleran naungan dan intoleran naungan yang ekstrim merupakan dua strategi ekologi yang sangat berbeda mengenai ciri suatu jenis pohon. Berkaitan dengan hal tersebut, maka Ducrey (1994) dalam Kriebitzch et al. (1997) menyatakan bahwa tumbuhan membutuhkan tingkat plastisitas fotosintetik dan morfologi yang tinggi supaya dapat beradaptasi terhadap naungan. Plastisitas morfologi tersebut ditunjukkan olch perbedaan nilai SLA (Specific Leaf Area) $\left(\mathrm{cm}^{2} \mathrm{~g}^{-1}\right)$, SLW (Specific Leaf Weight) $\left(\mathrm{g} \mathrm{cm}^{-2}\right)$, dan LA (Leaf Area) $\left(\mathrm{cm}^{2}\right)$ yang besar pada kondisi cahaya penuh dan kondisi ternaungi.

Selain perbedaan morfologi daun, perbedaan intensitas cahaya yang diterima tumbuhan juga akan memberikan perbedaan terhadap karakter anatomis daunnya. Tumbuhan yang hidup di bawah naungan yang berat selain lebih tipis, juga mempunyai sel-sel palisade yang lebih sedikit dibanding- kan dengan tumbuhan yang hidup pada cahaya penuh (Kimmins, 1987), selain itu daun naungan (shade leaves) mempunyai jumlah stomata yang lebih sedikit (Turner, 2001). Kedua karakter anatomi tersebut yang telah menunjukkan adanya efisiensi fotosintetik daun naungan yang lebih tinggi dibandingkan dengan daun cahaya (sun leaves), karena dengan jumlah stomata yang sedikit, daun dapat mengabsorpsi $\mathrm{CO}_{2}$ lebih mudah dan $\mathrm{H}_{2} \mathrm{O}$ mudah dievaporasi.

Tujuan penelitian ini adalah untuk mendapatkan informasi tentang sifat toleransi anakan ramin ( $G$. bancanus) yang tumbuh pada beberapa intensitas cahaya melalui pendekatan karakter morfologi (LA, SLA dan SLW) dan anatomi daun (tebal jaringan daun, tebal lapisan palisade, dan jumlah stomata per luasan daun) dikaitkan dengan respon pertumbuhan tinggi dan diameter tanaman $G$ bancanus pada tiga kondisi intensitas cahaya.

\section{METODOLOGI}

\section{A. Lokasi dan Waktu Penelitian}

Pengambilan contoh daun dan pengukuran tinggi dan diameter hasil percobaan penanaman anakan ramin dilakukan di plot penelitian Plasma Nutfah Ramin, Universitas Tanjungpura, Sei Bakau, Kabupaten Pontianak, Provinsi Kalimantan Barat, sedangkan kegiatan di laboratorium dilakukan di Laboratorium Silvikultur Pusat Penelitian dan Pengembangan Hutan dan Konservasi Alam, Bogor serta Laboratorium Silvikultur SEAMEO-BIOTROP, Bogor.

Kegiatan di lapangan dilakukan pada bulanApril 2005 dan kegiatan di laboratorium dilakukan pada bulan Mei sampai Juni 2005.

\section{B. Bahan dan Alat Penelitian}

\section{Bahan penelitian}

Bahan yang digunakan dalam penelitian ini adalah:

a. Tanaman $\operatorname{ramin}(G$ bancanus) umur dua tahun.

b. Data pengukuran tinggi dan diameter anakan ramin hasil percobaan penanaman yang dilakukan oleh tim peneliti Universitas Tanjungpura dan PT. 
Inhutani I (dikoleksi oleh Murniati et al., 2005).

c. Bahan-bahan kimia pembuat preparat jaringan dan stomata daun (alkohol, xylol, safranin, methylene blue, parafin, entilen).

d. Buku milimeter block.

\section{Alat penelitian}

Alat-alat yang digunakan dalam penelitian ini adalah oven, planimeter, alatalat untuk pembuatan preparat jaringan dan stomata daun (microtoome, waterbath, kaca objek dan kaca penutup, pipet, blok besi) serta mikroskop fluorescent.

\section{Metode Penelitian}

\section{Metode pengambilan data}

a. Pengamatan karakter morfologi dan anatomi daun menggunakan metode observasi yaitu berupa pengambilan contoh daun anakan berumur dua tahun dari tiga kondisi cahaya yaitu terbuka, agak terbuka, dan ternaungi. Masingmasing perlakuan diambil 15 helai dari kategori daun tua untuk keperluan analisis di laboratorium.

b. Data respon pertumbuhan anakan ramin diperoleh berdasarkan hasil pengamatan Murniati et al. (2005) terhadap keberhasilan penanaman ramin di lapangan. Data yang dikoleksi adalah tinggi dan diameter anakan ramin yang berumur dua tahun yang ditanam pada tiga kondisi cahaya di plot penelitian plasma nutfah ramin Universitas Tanjungpura, Sei Bakau, Kabupaten Pontianak, Provinsi Kalimantan Barat. Jumlah anakan yang diukur 10 individu untuk masing-masing kondisi cahaya.

\section{Parameter yang diamati}

a. Karakter morfologi daun : luas daun (Leaf Area-LA) $\left(\mathrm{cm}^{2}\right)$, luas daun spesifik (Specific Leaf Weight-SLA) $\left(\mathrm{cm}^{2} \mathrm{~g}^{-1}\right)$, dan bobot daun spesifik (Specific Leaf Weight - SLW) $\left(\mathrm{g} \mathrm{cm}^{-2}\right)$.

b. Karakter anatomi daun: tebal jaringan daun $(\mathrm{mm})$, tebal lapisan palisade (mm), dan jumlah stomata per luas daun $\left(\mathrm{N} \mathrm{cm}^{2}\right)$. c. Tinggi dan diameter anakan ramin umur dua tahun.

\section{Analisis data}

Data karakter morfologi, anatomi daun, tinggi, dan diameter anakan ramin umur dua tahun dengan perlakuan tiga kondisi cahaya yaitu terbuka (intensitas cahaya $>65 \%$ ), agak terbuka (intensitas cahaya 35-65\%), dan ternaungi (intensitas cahaya $<35 \%$ ), diulang 10 kali untuk karakter morfologi, tiga kali untuk karakter anatomi, dan untuk data tinggi dan diameter anakan ramin diulang 10 kali. Penelitian menggunakan Rancangan Acak Lengkap. Hasil analisis keragaman yang nyata diuji lebih lanjut dengan uji beda nyata Duncan.

\section{HASIL DAN PEMBAHASAN}

\section{A. Hasil}

\section{Karakter morfologi daun}

Berdasarkan analisis keragaman terhadap luas daun (LA), luas daun spesifik (SLA), dan bobot daun spesifik (SLW), maka diperoleh hasil seperti yang tertera pada Tabel 1.

Variabel SLA dan SLW menunjukkan perbedaan yang sangat nyata di antara ketiga perlakuan kondisi cahaya, sedang variabel luas daun tidak menunjukkan perbedaan yang nyata. Oleh karena itu untuk mengetahui perlakuan mana yang memberikan perbedaan yang nyata terhadap SLA dan SLW tersebut dilakukan uji beda nyata lanjut seperti tertera pada Tabel 2.

Hasil uji beda nyata pada Tabel 2 menunjukkan bahwa untuk respon SLA dan SLW terjadi keadaan yang bertentangan. Nilai SLA pada perlakuan naungan $(67,947$ $\mathrm{cm}^{2} \mathrm{~g}^{-1}$ ) lebih tinggi dibandingkan dengan perlakuan agak terbuka $\left(66,649 \mathrm{~cm}^{2} \mathrm{~g}^{-1}\right)$ dan terbuka( $\left(54,685 \mathrm{~cm}^{2} \mathrm{~g}^{-1}\right)$, sebaliknya nilai SLW pada perlakuan terbuka lebih tinggi $\left(0,0183 \mathrm{~g} \mathrm{~cm}^{-2}\right)$ dibandingkan dengan perlakuan agak terbuka $\left(0,0151 \mathrm{~g} \mathrm{~cm}^{-2}\right)$ dan naungan $\left(0,0148 \mathrm{~g} \mathrm{~cm}^{-2}\right)$. Namun secara statistik, baik SLA maupun SLW pada perlakuan agak terbuka dan naungan tidak menunjukkan perbedaan yang nyata. 
Tabel (Table) 1. Analisis variansi LA $\left(\mathrm{cm}^{2}\right)$, SLA $\left(\mathrm{cm}^{2} \mathrm{~g}^{-1}\right)$, dan SLW $\left(\mathrm{g} \mathrm{cm}^{-2}\right)$ anakan $G$ bancanus umur dua tahun pada tiga kondisi cahaya (Analysis of variance of LA, SLA and SLW of G. bancanus seedlings at two years age under three light conditions)

\begin{tabular}{|c|c|c|c|c|c|c|c|}
\hline \multirow{2}{*}{$\begin{array}{l}\text { Parameter } \\
\text { (Variable) }\end{array}$} & \multirow{2}{*}{$\begin{array}{l}\text { Sumber } \\
\text { (Source) }\end{array}$} & \multirow{2}{*}{$\begin{array}{l}\mathrm{Db} \\
(d f)\end{array}$} & \multirow{2}{*}{$\begin{array}{l}J K \\
(S S)\end{array}$} & \multirow{2}{*}{$\begin{array}{l}\mathrm{KT} \\
(M S)\end{array}$} & \multicolumn{3}{|c|}{ F } \\
\hline & & & & & Hit (calc) & 0,05 & 0,1 \\
\hline \multirow[t]{2}{*}{$\mathrm{LA}$} & Perlakuan & 2 & 2183,1729 & 1091,5865 & $1,13^{\text {เ }}$ & 3,35 & 5,49 \\
\hline & Galat & 27 & 25921,6819 & 960,0623 & & & \\
\hline \multirow[t]{2}{*}{ SLA } & Perlakuan & 2 & 1038,7080 & 519,3540 & $25,77^{*}$ & 3,35 & 5,49 \\
\hline & Galat & 27 & 543,9407 & 20,1459 & & & \\
\hline \multirow[t]{2}{*}{ SLW } & Perlakuan & 2 & 0,000074 & 0,000037 & $21,76^{*}$ & 3,35 & 5,49 \\
\hline & Galat & 27 & 0,000046 & 0,0000017 & & & \\
\hline
\end{tabular}

Keterangan (Note) : tn = tidak berbeda nyata (non significant)

** = berbeda sangat nyata (highly significant)

Tabel (Table) 2. Uji beda nyata rata-rata SL $\Lambda$ dan SLW anakan G bancanus umur dua tahun pada tiga kondisi cahaya (The significancy test of SLA and SLW of G. bancanus seedlings at two years age under three light conditions)

\begin{tabular}{llc}
\hline Parameter (Variable) & Perlakuan (Treatment) & Nilai rata-rata (Average) \\
\hline SLA $\left(\mathrm{cm}^{2} \mathrm{~g}^{-1)}\right.$ & Terbuka (Full sunlight) & $54,685^{\mathrm{a}}$ \\
& Agak terbuka (Moderate shading) & $66,649^{\mathrm{b}}$ \\
SLW $\left(\mathrm{g} \mathrm{cm}^{-2}\right)$ & Ternaungi (Heavy shading) & $67,947^{\mathrm{b}}$ \\
& Ternaungi (Heavy shading) & $0,0148^{\mathrm{a}}$ \\
& Agak terbuka (Moderate shading) & $0,0151^{2}$ \\
& Terbuka (Full sunlight) & $0,0183^{\mathrm{b}}$ \\
\hline
\end{tabular}

Keterangan (Note): Nilai pada suatu parameter yang diikuti olch huruf yang sama menunjukkan tidak berbeda pada taraf $1 \%$ berdasarkan uji jarak berganda Duncan (Values of each variable followed by the same. letter are not significantly different at $I \%$ level according to Duncan multiple range test)

\section{Karakter anatomi daun}

Berdasarkan variabel anatomi daun yang diamati, maka analisis variansi terhadap variabel tersebut dapat dilihat pada Tabel 3.

Di antara ketiga karakter anatomi yang diamati, maka yang berbeda nyata hanya jumlah stomata per luasan daun. Dengan demikian untuk mengetahui perlakuan yang memberikan perbedaan yang nyata terhadap jumlah stomata dilakukan uji beda nyata selanjutnya seperti tertera pada Tabel 4 .

Walaupun secara statistik jumlah stomata pada kondisi agak terbuka tidak berbeda nyata dengan kondisi ternaungi dan terbuka, namun jumlah stomata yang tertinggi terlihat pada perlakuan kondisi terbuka $(282,363)$ dibandingkan dengan kedua perlakuan yang lain (220,262 dan 205,306).

Penampilan jaringan dan stomata daun anakan ramin pada ketiga kondisi cahaya dapat dilihat pada Gambar 1 dan Gambar 2.

\section{Respon pertumbuhan tinggi dan diameter anakan ramin berumur dua tahun}

Analisis keragaman dari hasil pengukuran tinggi dan diameter anakan ramin di plot penelitian plasma nutfah ramin, Universitas Tanjungpura, Provinsi Kalimantan Barat tertera pada Tabel 5.

Anakan ramin yang telah berumur dua tahun menunjukkan perbedaan pertumbuhan yang sangat nyata pada ketiga kondisi cahaya. Oleh karena itu untuk mengetahui perlakuan kondisi cahaya yang memberikan perbedaan yang nyata terhadap tinggi dan diameter anakan G. bancanus, dilakukan uji beda nyata lanjutan seperti tertera pada Tabel 6.

Terlihat bahwa anakan yang tumbuh pada kondisi ternaungi mempunyai pertumbuhan tinggi dan diameter yang lebih lambat $(98,65$ $\mathrm{cm}$ dan 1,298 $\mathrm{cm}$ ) dibandingkan dengan 
Tabêl (Table) 3. Analisis variansi tebal jaringan (mm), tebal lapisan palisade (mm), dan jumlah stomata per luasan daun $\left(\mathrm{N} \mathrm{cm}{ }^{2}\right.$ ) anakan $G$ bancantes umur dua tahun pada tiga kondisi cahaya (Analysis of variance of leaf tissue thickness, palisade layer thickness, and the number of stomata per leaf area of $\mathrm{G}$. bancanus seedlings at two years age under three light conditions)

\begin{tabular}{|c|c|c|c|c|c|c|c|}
\hline \multirow[b]{2}{*}{ Parameter (Variable) } & \multirow{2}{*}{$\begin{array}{c}\text { Sumber variusi } \\
\text { (Source) }\end{array}$} & \multirow{2}{*}{$\begin{array}{l}\mathrm{Db} \\
(d f)\end{array}$} & \multirow{2}{*}{$\begin{array}{l}J K \\
(S S)\end{array}$} & \multirow[b]{2}{*}{$\begin{array}{c}\mathrm{KT} \\
(M S)\end{array}$} & \multicolumn{3}{|c|}{$\mathrm{F}$} \\
\hline & & & & & $\begin{array}{c}\text { Hit } \\
(\text { calc })\end{array}$ & 0,05 & 0,1 \\
\hline $\begin{array}{l}\text { Tebal jaringan daun } \\
\text { (Leaf tissue thickness) } \\
\text { (mm) }\end{array}$ & $\begin{array}{l}\text { Perlakuan } \\
\text { Galat }\end{array}$ & $\begin{array}{l}2 \\
6\end{array}$ & $\begin{array}{l}235,1744 \\
224,1408\end{array}$ & $\begin{array}{c}117,5872 \\
37,3568\end{array}$ & $3,14^{m}$ & 5,14 & 10,92 \\
\hline $\begin{array}{l}\text { Tebal lapisan palisade } \\
\text { (Palisade layer } \\
\text { thickness) (mm) }\end{array}$ & $\begin{array}{l}\text { Perlakuan } \\
\text { Galat }\end{array}$ & $\begin{array}{l}2 \\
6\end{array}$ & $\begin{array}{l}0,9728 \\
1,3814\end{array}$ & $\begin{array}{l}0.4864 \\
0.2302\end{array}$ & $2,11^{6}$ & 5,14 & 10,92 \\
\hline $\begin{array}{l}\text { Jumlah stomata per } \\
\text { luasan daun (The } \\
\text { numbers of stomata per } \\
\text { leaf area })\left(\mathrm{N} \mathrm{cm}^{-2}\right)\end{array}$ & $\begin{array}{l}\text { Perlakuan } \\
\text { Galat }\end{array}$ & $\begin{array}{l}2 \\
6\end{array}$ & $\begin{array}{c}10018,1829 \\
2543,7611\end{array}$ & $\begin{array}{l}5009,0914 \\
423,9601\end{array}$ & $11,81^{m}$ & 5,14 & 10,92 \\
\hline
\end{tabular}

Tabel (Table) 4. Uji beda nyata rata-rata jumlah stomata per luasan daun $\left(\mathrm{N} \mathrm{cm}^{2}\right)$ anakan (i bancanus umur dua tahun pada tiga kondisi cahaya (The significancy test of the numbers of stomata per leaf area of $\mathrm{G}$ bancanus seedlings at two years age under three light conditions)

\begin{tabular}{llc}
\hline Parameter (Variable) & Perlakuan (Treatment) & Nilai rala-rata (Average) \\
\hline Jumlah stomata per luasan & Ternaungi (Heavy shading) & $205,306^{\circ}$ \\
daun (The numbers of stomata & Agak terbuka (Moderate shading) & $220,262^{\text {ab }}$ \\
per leaf area $)\left(\mathrm{N} \mathrm{cm}^{-2}\right)$ & Terbuka (Full sunlight) & $282,363^{\mathrm{b}}$ \\
\hline
\end{tabular}

Keterangan (Note): Nilai pada suatu parameter yang diikuti oleh huruf yang sama menunjukkan tidak berbeda pada taraf $1 \%$ berdasarkan uji jarak berganda Duncan (Values of each variable followed by the same letter are not significantly different at / \% level according to Duncan multiple range test)

Tabel (Table) 5. Uji beda nyata rata-rata tinggi $(\mathrm{cm})$ dan diameter $(\mathrm{cm})$ anakan $G$ bancanus umur dua tahun pada tiga kondisi cahaya (The significancy test of the high and diameter of $\mathrm{G}$ bancanus seedlings at two years age under three light conditions)

\begin{tabular}{|c|c|c|c|c|c|c|c|}
\hline \multirow{2}{*}{$\begin{array}{l}\text { Purameter } \\
\text { (Variahle) }\end{array}$} & \multirow{2}{*}{$\begin{array}{l}\text { Sumber } \\
\text { (Source) }\end{array}$} & \multirow{2}{*}{$\begin{array}{l}\mathrm{Db} \\
(d f)\end{array}$} & \multirow{2}{*}{$\begin{array}{c}\text { JK } \\
(S S) \\
\end{array}$} & \multirow{2}{*}{$\begin{array}{c}\mathrm{KT} \\
(M S)\end{array}$} & \multicolumn{3}{|c|}{$\mathrm{F}$} \\
\hline & & & & & Hit (calc) & 0.05 & 0,1 \\
\hline Tinggi $(H i g h)(\mathrm{cm})$ & Perlakuan & 2 & 13266,438 & 6633,219 & $5,52 * *$ & 3,35 & 5,49 \\
\hline & Galat & 27 & 32389,582 & 1199,614 & & & \\
\hline $\begin{array}{l}\text { Diamcter (Dicmeter) } \\
(\mathrm{cm})\end{array}$ & Perlakuan & 2 & 1,4258 & 0,7129 & $14,72 * *$ & 3,35 & 5,49 \\
\hline
\end{tabular}

Keterangan (Note) : ** = berbeda sangat nyata (highly significanf)
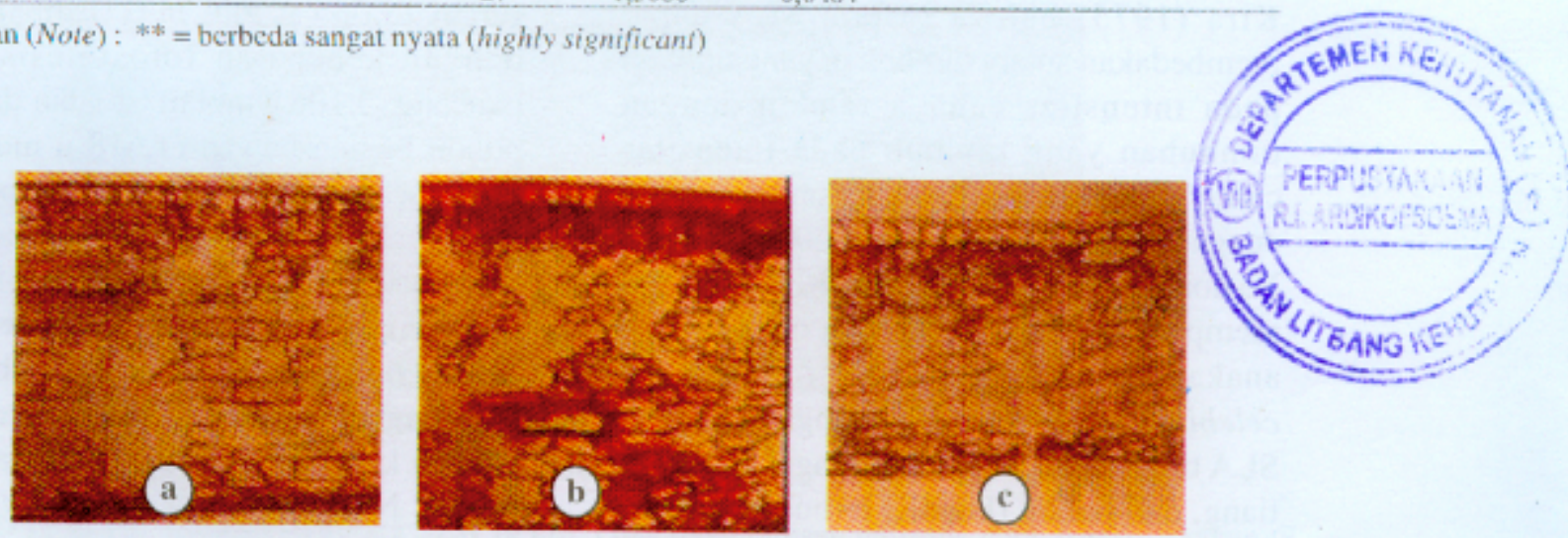

Gambar (Figure) 1. Sayatan paradermal juringan daun anakan G. bencanus pada kondisi ternaungi (a) (40 kali perbesaran); agak terbuka (b) (20 kali perbesaran); cuhaya terbuka (c) (20 kali perbesaran) (Paradermal section of leaf tissue of $\mathrm{G}$. bancanus seedlings under heavy shading $(a)$; moderate shading (b); full sunlight $(c)$ ) 

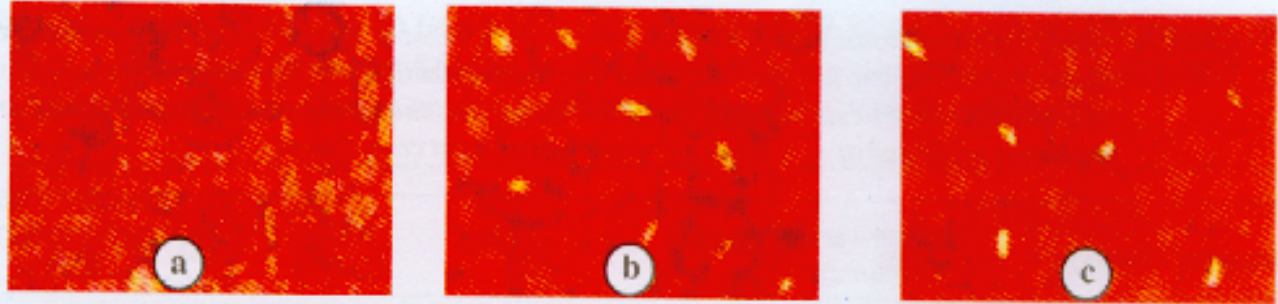

Gambar (Figure) 2. Penampilan stomata anakan G bancanus per luasan bidang pandang $\left(0,33 \mathrm{~mm}^{2}\right)$ pada kondisi cahaya ternaungi (a) (40 kali perbesaran); agak terbuka (b) (40 kali perbesaran); terbuka (c) (40) kali perbesaran) (Appereance of stomata of $\mathrm{G}$ bancanus seedlings per microscope area $\left(0.33 \mathrm{~mm}^{2}\right)$ under heavy shading $(a)$; moderate shading (b); full sunlight $(c)$ )

Tabel (Table) 6. Uji beda nyata rata-rata tinggi dan diameter anakan $G$ bancunus umur dua tahun pada tiga kondisi cahaya (The significancy test of the height and diameter of $\mathrm{G}$. bancanus seedlings at iwo years age under three light conditions)

\begin{tabular}{|c|c|c|}
\hline Parameter (Variable) & Perlakuan (Treatment) & Nilai rata-rata (Average) \\
\hline Tinggi $(H i g h)(\mathrm{cm})$ & $\begin{array}{l}\text { Ternaungi (Heavy shading) } \\
\text { Agak terbuka (Moderate shading) } \\
\text { Terbuka (Full sunlight) }\end{array}$ & $\begin{array}{c}98,65^{n} \\
141,13^{*} \\
145,12^{b}\end{array}$ \\
\hline Diameter (Diameter) $(\mathrm{cm})$ & $\begin{array}{l}\text { Ternaungi (Heavy shading) } \\
\text { Agak terbuka (Moderate shading) } \\
\text { Terbuka (Full sunlight) }\end{array}$ & $\begin{array}{l}1,298^{4} \\
1,536^{2} \\
1,831^{b}\end{array}$ \\
\hline
\end{tabular}

Keterangan (Note): Nilai suatu parameter yang diikuti oleh huruf yang sama menunjukkan tidak berheda pada taraf $1 \%$ berdasarkan uji jarak berganda Duncan (Values of each variable followed by the same letter are not significantly different as / \% level according to Duncan multiple range test)

anakan yang tumbuh pada kondisi agak terbuka $(141,12 \mathrm{~cm}$ dan $1,536 \mathrm{~cm})$ dan terbuka $(145,12 \mathrm{~cm}$ dan $1,831 \mathrm{~cm})$.

\section{B. Pembahasan}

Berdasarkan hasil uji beda nyata terhadap SLA dan SLW (Tabel 2), maka terlihat bahwa semakin terbuka ruang tumbuh tanaman, ukuran daun akan makin kecil dan makin tebal. Seperti yang dikemukakan oleh Kira (1975) bahwa respon SLA dapat membedakan antara tumbuhan yang tumbuh pada intensitas cahaya rendah dengan tumbuhan yang tumbuh pada intensitas cahaya tinggi. Keadaan tersebut sejalan dengan penelitian Rostiwati (2005) di Taman Nasional Lore Lindu, Sulawesi Tengah yang memperoleh hasil bahwa SLA daun tingkat anakan (kondisi ternaungi) Lithocarpus celebicus lebih besar dibandingkan dengan SLA tingkat pancang (kondisi agak terbuka), tiang, dan pohon (kondisi terbuka), sedang pada SLW terjadi keadaan sebaliknya yaitu SLW daun tingkat anakan lebih rendah dibandingkan SLW daun tingkat pancang, tiang, dan pohon. Hal tersebut terkait dengan strategi tumbuhan meningkatkan intersepsi cahaya dan pemanfaatan cahaya untuk fotosintesis (Levitt, 1980), sehingga pada kondisi yang ternaungi tumbuhan akan berupaya untuk dapat meningkatkan kemampuan fotensintesisnya. Efisiensi pemanfaatan cahaya pada tumbuhan ternaungi ini dapat terlihat dari hasil penelitian Rostiwati (2005) bahwa kecepatan fotosintesis daun anakan $L$. celebicus lebih tinggi $\left(5,065 \mu \mathrm{mol} \mathrm{m}^{-2} \mathrm{~s}^{-1}\right)$ dibandingkan dengan kecepatan fotosintesis tingkat pancang $\left(3,106 \mu \mathrm{mol} \mathrm{m}^{-2} \mathrm{~s}^{-1}\right)$ dan daun tajuk pohon bagian bawah $\left(1,618 \mu \mathrm{mol} \mathrm{m}^{-2} \mathrm{~s}^{-1}\right)$. Hal tersebut berarti bahwa adanya perbedaan karakter fotosintetik di antara kelompok tumbuhan (toleran, semitoleran, dan intoleran) merupakan indikasi adanya perbedaan strategi tumbuhan agar dapat bertahan hidup pada lingkungan tempat tumbuhnya. Terkait dengan karakter tersebut, maka kandungan unsur $\mathrm{N}$ daun juga memperlihatkan keistimewaan yang nyata dalam proses fotosintesis tumbuhan. Oleh karena tumbuhan yang berbeda tingkat toleransinya akan berbeda pula kemampuan meresorpsi 
$\mathrm{N}$ daunnya. Perbedaan sifat ini yang menyebabkan perbedaan akan regulasi penangkapan cahaya dan $\mathrm{CO}_{2}$ serta asimilasi hara-hara fotosintetik (khususnya N). Lusk dan Contreras (1999) mengemukakan bahwa terlihat adanya perbedaan resorpsi $\mathrm{N}$ antara tumbuhan toleran, intoleran, dan semitoleran naungan. Resorpsi $\mathrm{N}$ yang paling tinggi ditunjukkan oleh jenis intoleran $( \pm 69,58 \%)$, kemudian diikuti oleh jenis semitoleran ( \pm $62,8 \%$ ), dan toleran naungan ( $\pm 51,75 \%$ ).

Parameter luas daun (LA) tidak menunjukkan perbedaan yang nyata, karena variabel ini perlu dihubungkan dengan parameter lainnya, seperti jumlah stomata, kandungan hara daun, kandungan karbohidrat daun. Dengan demikian variabel LA ini merupakan variabel yang menunjukkan strategi struktural saja, tidak dapat menunjukkan strategi fungsional dari tumbuhan tersebut.

Berbeda dengan mekanisme toleransi yang terjadi pada anakan $L$. celebicus yang menunjukkan adanya perbedaan yang nyata antara tebal jaringan dan tebal lapisan palisade daun anakan (ternaungi) dengan tebal jaringan dan tebal lapisan palisade daun pancang (agak terbuka) dan tiang serta pohon (terbuka), pada anakan $G$ bancanus tidak terlihat adanya perbedaan yang nyata antara tebal jaringan dan tebal lapisan palisade antara daun anakan pada kondisi ternaungi (intensitas cahaya $<35 \%$ ), agak terbuka (intensitas cahaya 35-65\%), dan terbuka (> $65 \%$ ) (Tabel 3 dan Gambar 1).
Lapisan jaringan palisade merupakan salah satu lapisan yang terdiri atas sel-sel mesofil palisade yang banyak mengandung klorofil. Klorofil adalah unit fotosintetik yang berperan dalam penangkapan energi matahari. Oleh karena bobot daun spesifik (SLW) merupakan cerminan dari daun-daun tanaman yang tumbuh pada kondisi terbuka, maka keragaman yang dapat ditunjukkan oleh lapisan jaringan palisade pada parameter SLW dapat terlihat dari model regresinya (Gambar 3). Berdasarkan analisis hubungan tersebut, $\mathrm{R}^{2}$ menunjukkan nilai $54,16 \%$. Artinya hanya 54,16\% keragaman nilai SLW dapat diterangkan oleh model tersebut. Hal ini berbeda dengan yang ditunjukkan oleh $L$. celebicus, diperoleh bahwa $\mathrm{R}^{2}$ dari hubungan antara SLW dan tebal lapisan palisade daun L. celebicus yang lebih besar yaitu $69,37 \%$. Artinya keragaman nilai SLW dapat menerangkan $69,37 \%$ tebal lapisan palisade daun $L$. celebicus (Rostiwati, 2005).

Berdasarkan perbedaan karakter anatomi antara $L$. celebicus dengan $G$. bancanus tersebut, maka sifat toleransi keduanyapun berbeda. Hasil penelitian Rostiwati (2005) menyebutkan bahwa $L$. celebicus merupakan jenis yang mempunyai sifat toleran terhadap naungan (shade tolerant species), sedangkan $G$ bancanus mempunyai sifat semitoleran (semi-tolerant species) (Muin dan Purwita, 2002). Artinya untuk mengatasi intensitas cahaya yang tinggi, maka pada jenis intoleran, cahaya akan ditransmisi, diabsorpsi, dan direfleksikan

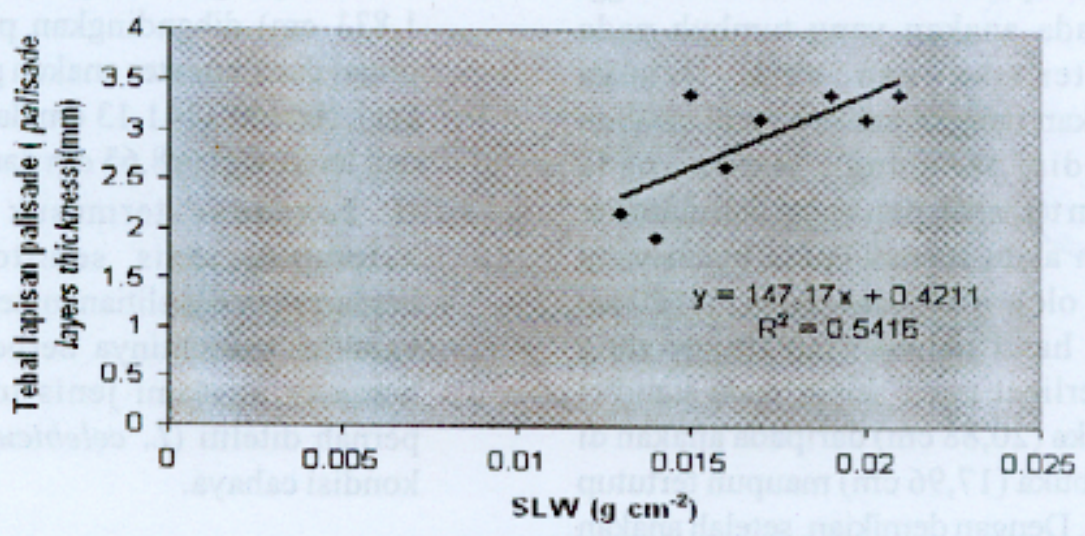

Gambar (Figure) 3. Hubungan antara SLW $\left(\mathrm{g} \mathrm{cm}^{-2}\right)$ dan tebal lapisan palisade daun (mm) anakan $G$ bancanus umur dua tahun pada tiga kondisi cahaya (Regression between SLW and palisade layers thickness of $\mathrm{G}$ bancanus seedlings at two years age under three light conditions) 
beberapa kali melalui lapisan palisadenya yang tebal, sehingga asimilasi dan resorpsi nutrisi untuk fotosintesis berjalan secara terus menerus, selain itu pula absorpsi cahaya pada daun-daun dengan lapisan mesofil yang tebal akan meningkat 3,5 kali dalam satu detik pada setiap bagian lapisan pengabsorpsi aktif radiasi cahaya (Kriedemann, 1999).

Berbeda dengan mekanisme yang terjadi pada jenis toleran, perbedaan yang sangat kritis terjadi pada karakter anatomi tingkat anakan ke tingkat pancang (Rostiwati, 2005). Pada jenis semitoleran seperti pada penelitian ini, ternyata $G$. bancanus sejak tingkat anakan sudah membutuhkan cahaya yang lebih besar dibandingkan dengan yang dibutuhkan oleh anakan $L$. celebicus, yaitu agak terbuka $( \pm 65 \%)$ dan tebal lapisan palisadenyapun tidak memperlihatkan perbedaan yang nyata. Namun berdasarkan hasil uji beda nyata terhadap jumlah stomata per luasan daun, maka yang memberikan perbedaan menonjol adalah pada mekanisme regulasi $\mathrm{CO}_{2}$ oleh stomata. Stomata dengan jumlah yang lebih banyak ditunjukkan oleh anakan yang tumbuh di kondisi terbuka dibandingkan dengan anakan pada kondisi agak terbuka dan ternaungi.

Perbedaan regulasi tersebut terkait dengan kecepatan fotosintesis untuk pertumbuhan anakan di ketiga kondisi cahaya. Hal tersebut terlihat dari hasil pengamatan terhadap respon pertumbuhan tinggi dan diameter anakan $G$ bancanus yang tertera pada Tabel 5. Ternyata, baik pertumbuhan tinggi maupun pertumbuhan diameter tertinggi terlihat pada anakan yang tumbuh pada kondisi terbuka dan agak terbuka dibandingkan dengan anakan yang tumbuh pada kondisi ternaungi. Namun pada pengamatan terhadap riap tinggi dan diameter permudaan alam selama enam bulan yang dilakukan oleh Muin dan Purwita (2002) diperoleh hasil bahwa riap tinggi yang terbesar terlihat pada semai pada kondisi agak terbuka $(20,88 \mathrm{~cm})$ daripada anakan di tempat terbuka $(17,96 \mathrm{~cm})$ maupun tertutup $(11,61 \mathrm{~cm})$. Dengan demikian, setelah anakan berumur dua tahun, mekanisme efektivitas dan efisiensi sumberdaya alam (air, nutrisi, dan cahaya) terlihat dari kemampuan tumbuhan meningkatkan pertumbuhan tinggi dan diameternya.

Akan tetapi, dengan lebih besarnya pertumbuhan tinggi dan diameter anakan berumur dua tahun pada kondisi terbuka (Tabel 6), telah memberi dugaan bahwa strategi anatomi terhadap intensitas cahaya yang diterima anakan $G$, bancanus berbeda dengan strategis anatomi $L$. celebicus. Pendapat tersebut akan dapat disempurnakan dengan pengamatan kecepatan fotosintesis anakan $G$ bancanus tersebut pada tiap kondisi cahaya.

\section{KESIMPULAN DAN SARAN}

\section{A. Kesimpulan}

1. Specific Leaf Area tanaman yang tumbuh pada kondisi ternaungi lebih besar $\left(67,947 \mathrm{~cm}^{2} \mathrm{~g}^{-1}\right)$ dibandingkan dengan Specific Leaf Area anakan yang tumbuh pada kondisi agak terbuka $\left(66,649 \mathrm{~cm}^{2}\right.$ $\left.\mathrm{g}^{-1}\right)$ dan terbuka $\left(54,685 \mathrm{~cm}^{2} \mathrm{~g}^{-1}\right)$, sedang Specific Leaf Weight anakan yang ternaungi lebih rendah $\left(0,0148 \mathrm{~g} \mathrm{~cm}^{-2}\right)$ dibandingkan dengan Specific Leaf Weight anakan yang tumbuh pada kondisi agak terbuka $\left(0,0151 \mathrm{~g} \mathrm{~cm}^{-2}\right)$ dan terbuka $\left(0,0183 \mathrm{~g} \mathrm{~cm}^{-2}\right)$.

2. Jumlah stomata per luasan daun anakan berbeda sangat nyata di antara tiga kondisi cahaya, jumlah stomata yang lebih banyak pada anakan yang tumbuh pada kondisi terbuka $(282,36)$ yang mendukung pertumbuhan tinggi dan diameter yang lebih cepat $(145,12 \mathrm{~cm}$ dan $1,831 \mathrm{~cm}$ ) dibandingkan pertumbuhan tinggi dan diameter anakan pada kondisi agak terbuka $(141,13 \mathrm{~cm}$ dan $1,536 \mathrm{~cm})$ dan ternaungi $(98,65 \mathrm{~cm}$ dan $1,298 \mathrm{~cm})$.

3. G. bancanus termasuk ke dalam kelompok jenis semitoleran dan berdasarkan penelitian ini terlihat bahwa karakter anatominya berbeda dengan karakter anatomi jenis toleran yang pernah diteliti (L. celebicus) pada tiga kondisi cahaya.

\section{B. Saran}

Untuk lebih melengkapi karakter fungsional daun anakan ramin lainnya, maka 
perlu pengamatan aspek fisiologi daun yaitu fotosintesis dan kandungan hara (khususnya N) daun.

\section{DAFTAR PUSTAKA}

Anonymous. 1994. Ramin (Gonystylus spp) masuk Appendix II dalam konvensi perdagangan internasional spesies flora dan fauna, CITES. Kronik, MKI Edisi VI.

Kimmins, J. P. 1987. Forest ecology. Mac Millan Publishing Company, New York.

Kira, T. 1975. Primary production of forests. Dalam: Photosynthesis and productivity in different environments (Cooper, J. P., editor). The Cambridge University Press, New York, USA: 5-40.

Kriebitzch, W. V., H. Hullerstael and C. The. 1997. Photosynthesis and growth of seedlings of two tree species from Southeast Asia at different light regimes. Plant Research and Development 46:100-107.

Kriedemann, P. 1999. Light use and leaf gas exchange. Dalam: Plants in action (Atwell, B. P. Kriedemann \& C. Turnbull, editors). MacMillan Education Australia Pty Ltd, New Zealand, Australia.

Levitt, J. 1980. Response of plants to environmental stresses: water, radiation, salt and other stresses. Vol II. Academic Press, London.

Lusk, C. H. and O. Contreras. 1999. Foliage area and crown nitrogen turnover in temperate rain forest juvenile trees of differing shade tolerance. Journal of Ecology 87 : 973-983.

Muin, A. and T. Purwita. 2002. Intensitas cahaya untuk pemeliharaan permudaan alam dan penanaman ramin (Gonystylus bancanus (Miq.) Kurz) pada areal bekas tebangan eks HPH PT. Munsim PT. Inhutani II. MKI, VI : 9-13.

Murniati, T. Rostiwati and Hendromono. 2005. Review and current status of ramin plantation activities. Technical report ITTO Pre-Project. Forestry Research and Development Agency. (In press)

Rostiwati, T. 2005. Mekanisme adaptasi Lithocarpus celebicus (Miq.) Rehd terhadap naungan pada tegakan hutan alam di Taman Nasional Lore Lindu, Sulawesi Tengah. Disertasi. Sekolah Pascasarjana Institut Pertanian Bogor, Bogor. Tidak diterbitkan.

Turner, I. M. 2001. The Ecology of trees in the tropical rain forest. Cambridge University Press, United Kingdom.

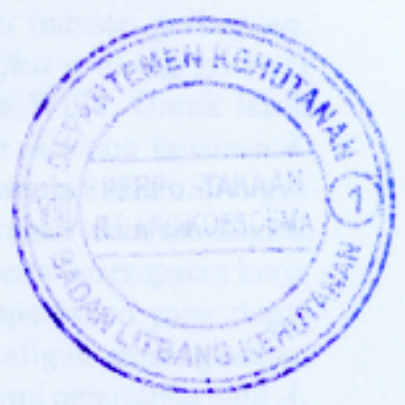

